\title{
Evaluation of the Antioxidants and Antimicrobial Properties of Two Nigerian Leafy Vegetables
}

\author{
Borokini Funmilayo Bosede $^{1, *}$, Adesuyi Ayodeji Temitope ${ }^{2}$, Komolafe Olamide Yemisi $^{2}$ \\ ${ }^{1}$ Department of Chemistry, University of Medical Science, Laje, Ondo City, 0340001, Ondo State, Nigeria \\ ${ }^{2}$ Department of Science Laboratory Technology, Rufus Giwa Polytechnic, Owo, P.M.B. 1019, Ondo State, Nigeria \\ *Corresponding author: borokinif59@yahoo.com
}

\begin{abstract}
The study was carried out on Senecio biafrae and Basella alba to promote their utilization as a support for promoting healthy diets. Phytochemical screening and determination of reducing power of different concentrations (1-5 mg ml ${ }^{-1}$ ) of the aqueous and alcoholic extracts; using ferric reducing antioxidant assay and phosphomolybdate method were carried out. The antimicrobial activities of the extracts against selected pathogen at $0.05 \mathrm{~g} / \mathrm{ml}$ were evaluated by using agar well diffusion method for antibacterial and poisoned food technique for antifungal assays. The results revealed the presence of flavonoid, tannin, terpenoid and saponin in the extracts. Correlation analysis revealed positively strong correlation between the total flavonoid content (TFC) and total phenol content (TPC) with the reducing property. For ferric reduction, the range was TFC $(r=0.944-0.967)$ and TPC $(r=0.937-0.970)$ for B.alba extracts and TFC $(r=0.918-0.976)$ and TPC $(r=0.947-0.990)$ for S. bifrae at between 0.01 and 0.05 significant levels. All the fractions showed concentration dependent increase in their total antioxidant property (TAP) with positively strong correlations with corresponding TFC and TPC in the range TFC $(\mathrm{r}=0.971-0.991)$; TPC $(\mathrm{r}=0.945-0.980)$ for B. alba and TFC $(\mathrm{r}=0.957-0.983)$; TPC $(\mathrm{r}=0.966-0.991)$ for $S$. biafrae at 0.01- 0.05 significant levels. The vegetables exhibited mild antibacterial activities against Staphylococcus aureus, Pseudomonas aeruginosa and Salmonella typhi compared with streptomycin sulphate used as control but appreciable antifungal activities against (Fusarium solani, Trichoderma rubrum and Aspergillus fumigates) compared with bonlate antibiotic positive control. The vegetables possess appreciable antioxidant and antimicrobial properties for promoting good health, their cultivation and utilization should be encouraged especially in the face of health and economic challenges; and food insecurity in many parts of the world.
\end{abstract}

Keywords: vegetables, extracts, phytochemicals, antimicrobial, reducing property

Cite This Article: Borokini Funmilayo Bosede, Adesuyi Ayodeji Temitope, and Komolafe Olamide Yemisi, "Evaluation of the Antioxidants and Antimicrobial Properties of Two Nigerian Leafy Vegetables." Journal of Food and Nutrition Research, vol. 5, no. 6 (2017): 418-426. doi: 10.12691/jfnr-5-6-9.

\section{Introduction}

Plants like fruits, vegetables and medicinal plants possess many biologically active compounds, making them potential source of therapeutic agents since ancient times [1,2]. There is increasing interest in the use of natural products because of several lethal diseases which are now very common in modern times; and scientific evidences abound that majority of these chronic conditions are related to diet and life style. There is a wide spread belief now that natural food and medicine are healthier than processed and synthetic products. This is why food based approach and development of new drugs from natural products are considered important interventions in the action plan against chronic diseases. World Health Organization (WHO) therefore encourages countries to identify and exploit traditional medicine and phytotherapy [3]. The presence of phytochemicals in vegetables explains the reason for their use in ethno medicine for the treatment and management of various ailments [4]. Investigations for functional food ingredients and nutraceutical products are important nowadays to promote health and reduce risk of disease. Senecio biafrae and Basella alba are among the numerous underutilized indigenous vegetables in Nigeria. S. biafrae (with local name "worowo" by Yoruba tribe in Nigeria) is a common undercover crop in cocoa plantations, in south-western Nigeria. Fresh succulent leaves of Senecio biafrae are used as food, usually cooked as a leafy vegetable for its unique taste, and flavour, especially among the rural and local population. Studies have established its substantial nutritional and medicinal value $[5,6,7]$.

B. alba, locally called "Amunu-tutu" in southwestern part of Nigeria is a short lived perennial herb which belongs to the family Basellaceae. The young leaves, stem and shoots, which make a succulent, slightly mucilaginous vegetable are used in cooking; they could be eaten cooked as green vegetables or added to soups [8]. B. alba has been found to be a good source of calcium, iron, magnesium, vitamin A, vitamin B9 (folic acid), vitamin C and several vital anti-oxidants [2]. Though the consumption of B. alba is more common in Nigeria, it is yet to take its proper place as a potential economy vegetable. Few stands of Basella are commonly cultivated 
at the backyard for consumption in many homes. Vegetables can play an important role in improvement of economy and social status of the citizen in addition to their positive effects on human health. Many studies have been carried out on the nutritional values of many vegetables in Nigeria [2,9] but there is need for more information on the antimicrobial properties of many of these vegetables, as an indicator of their possible therapeutic potential. In the present study, attempt was made to screen the alcohol and aqueous extracts of the above mentioned vegetables for phytochemicals, determine their reducing properties and their antimicrobial activities

\section{Materials and Methods}

\subsection{Preparation of Samples and Extracts}

The air-dried samples of $B$. alba; a perennial vine which belongs to family Basellaceae and $S$. biafrae also a perennial climbing herb known as English spinach were purchased from local markets in Nigeria, ground and sieve to give $40 \mathrm{~mm}$ mesh size powder. Bioactive extract of each powdered vegetable was obtained by weighing $20 \mathrm{~g}$ into clean and dried reagent bottle and $400 \mathrm{ml}$ each of distilled water, methanol and ethanol were separately added and subjected to cold maceration process for $24 \mathrm{~h}$ to obtain the aqueous extract and $72 \mathrm{~h}$ to obtain the alcohol extracts. The extracts were concentrated under vacuum and evaporated using rotary evaporator at low temperature $\left(45^{\circ} \mathrm{C}\right)$. The extracts were kept for analyses [10].

\subsection{Phytochemical Screening of the Extracts}

Phytochemical screening of the extracts were carried out using standard qualitative phytochemical methods described by Harborne [11]. Trease and Evans [12] and Sofowora [13].

\subsubsection{Alkaliod Determination}

About $0.5 \mathrm{ml}$ of each extract was stirred in $5 \mathrm{ml}$ of $1 \%$ aqueous $\mathrm{HCl}$ on a steam water bath, $1 \mathrm{ml}$ of the filtrate was treated with a few drops of Dragendorf reagent, blue black turbidity was taken as preliminary evidence for the presence of alkaloid.

\subsubsection{Saponin Determination}

The ability of saponin to produce frothing in aqueous solution was used as screening test for saponin. About 0.5 $\mathrm{ml}$ of each extract was shaken with distilled water in a test tube, frothing which persist on warming was taken as preliminary evidence for the presence of saponin.

\subsubsection{Tannin Determination}

About $0.5 \mathrm{ml}$ of each extract was stirred with $100 \mathrm{ml}$ of distilled water, filtered and ferric chloride reagent was added to the filtrate. A blue black green or blue green precipitate was taken as evidence for presence of tannin.

\subsubsection{Flavonoid Determination}

About $0.5 \mathrm{ml}$ of each extract was stirred with $20 \mathrm{ml}$ of dilute ammonia solution. A yellow colouration was observed, the disappearance of the yellow colour after the addition of $1 \mathrm{ml}$ conc. $\mathrm{H}_{2} \mathrm{SO}_{4}$ indicated the presence of flavonoid.

\subsubsection{Steriod Determination}

Exactly $20 \mathrm{ml}$ of acetic anhydride was added to $0.5 \mathrm{~g} \mathrm{ml}$ of each extract and filtered, $2 \mathrm{ml}$ of concentrated $\mathrm{H}_{2} \mathrm{SO}_{4}$ was added to the filtrate. There was a colour change from violet to blue or green which indicate the presence of steroid.

\subsubsection{Terpenoid Determination}

About $0.5 \mathrm{ml}$ of each extract was mixed with $20 \mathrm{ml}$ of chloroform and filtered. $3 \mathrm{ml}$ of concentrated $\mathrm{H}_{2} \mathrm{SO}_{4}$ was added to the filtrate to form a layer. A reddish brown colour at the interface was observed which indicated the presence of terpeniod.

\subsubsection{Anthraquinone Determination}

Borntrager's test was used for the detection of anthraquinone. $0.5 \mathrm{ml}$ of the extract was shaken with 10 $\mathrm{ml}$ of benzene, filtered and $5 \mathrm{ml}$ of $10 \%$ ammonia solution added to the filtrate. The mixture was shaken and the presences of pink red or violet colour in the ammonia layer indicated the presence of free anthraquinone.

\subsubsection{Phlobatannin Detemination}

Deposition of red precipitate when $0.5 \mathrm{ml}$ of each of the extracts was boiled with $1 \%$ aqueous $\mathrm{HCl}$ was taken as the evidence for the presence of phlobatannin.

\subsubsection{Cardiac Glycosides Determination}

\subsubsection{Legal's Test}

About $0.5 \mathrm{ml}$ of each extract was dissolve in pyridine and a few drops of $2 \%$ sodium nitroprusside with few drops of $20 \% \mathrm{NaOH}$ were added. A deep red colouration which faded to a brownish yellow indicates the presence of cardenolides.

\subsubsection{Salkowski's Test}

About $0.5 \mathrm{ml}$ of each extract was mixed with $20 \mathrm{ml}$ of chloroform and filtered. $3 \mathrm{ml}$ of concentrated $\mathrm{H}_{2} \mathrm{SO}_{4}$ was added to the filtrate to form a layer. A reddish brown colour at the interface was observed which indicate the presence of steroidal ring.

\subsubsection{Keller- killiani's Test}

About $0.5 \mathrm{ml}$ of each extract was dissolve in $2 \mathrm{ml}$ of glacial acetic acid containing one drop of ferric chloride solution. This was then under layer with $1 \mathrm{ml}$ of concentrated $\mathrm{H}_{2} \mathrm{SO}_{4}$. A brown colouration obtained at the interface indicated the presence of a deoxy sugar, which is a characteristic of cardenolides.

\subsubsection{Lieberman's Test}

Exactly $20 \mathrm{ml}$ of acetic anhydride was added to $0.5 \mathrm{ml}$ of each of the extract and filtered. $2 \mathrm{ml}$ of concentrated $\mathrm{H}_{2} \mathrm{SO}_{4}$ was added to the filtrate. There was a colour change from violet to blue or green which indicated the presence of steroids nucleous.(i.e aglycone portion of the cardiac glycosides). 


\subsection{Determination of Ferric Reducing Antioxidant Property (FRAP)}

The reducing property of the extract was determined by assessing the ability of the extracts to reduce $\mathrm{FeCl}_{3}$ solution as described by Pulido et al., [14]. Each of the extracts $(1-5 \mathrm{mg} / \mathrm{ml})$ was mixed with $2.5 \mathrm{ml}, 200 \mathrm{mM}$ sodium phosphate buffer ( $\mathrm{pH} 6.6$ ) and $2.5 \mathrm{ml}$ of $1 \%$ potassium hexacyanoferrate (III) $\left(-\mathrm{K}_{3}\left[\mathrm{Fe}(\mathrm{CN})_{6}\right]\right)$. The mixture was incubated at $50^{\circ} \mathrm{C}$ for $20 \mathrm{~min}$, thereafter $2.5 \mathrm{ml}, 10 \%$ Trichloroacetic acid was also added and subsequently centrifuged at $650 \mathrm{rpm}$ for $10 \mathrm{~min}, 5 \mathrm{ml}$ of the supernatant was then mixed with equal volume of water and $1 \mathrm{ml}$ of $0.1 \% \mathrm{FeCl}_{3}$. The absorbance was measured at $700 \mathrm{~nm}$, the higher the absorbance, the higher the reducing power.

\subsection{Determination of Total Antioxidant Property (TAP)}

The assay is based on the reduction of Mo (VI) - Mo (V) by the extracts and the subsequent formation of a green phosphate/Mo (V) complex at acidic $\mathrm{pH}$ as described by Prieto et al., [15]. Exactly $0.2 \mathrm{ml}$ of the different extracts $(1-5 \mathrm{mg} / \mathrm{ml})$ was each combined with $3 \mathrm{ml}$ of reagent solution (0.6 $\mathrm{M} \mathrm{H}_{2} \mathrm{SO}_{4}, 28 \mathrm{mM} \mathrm{Na}_{3} \mathrm{PO}_{4}$ and $4 \mathrm{Mm}$ $\left.(\mathrm{NH} 4)_{2} \mathrm{MoO}_{4}\right)$. The tubes were incubated at $95^{\circ} \mathrm{C}$ for 90 min and the absorbance measured at $695 \mathrm{~nm}$ against the blank after the mixtures have cooled to room temperature. The antioxidant activity was expressed as gallic acid equivalent.

\subsection{Determination of Antimicrobial Activity}

\subsubsection{Determination of Antibacterial Activity}

The bacterial isolates used were identified and subsequently maintained as stock strains. Simple susceptibility screening test using agar well diffusion method was employed and each bacterial isolate was suspended in sterile saline and diluted to $10^{6}$ colony forming unit $(\mathrm{CFU}) / \mathrm{ml}$. The antibacterial activity of aqueous, methanolic and ethanolic extracts of the vegetables against bacterial isolates ( $S$. aureus, $P$. aeruginosa, and $S$. typhi) was evaluated by using agar well diffusion method [16,17]. Plate count agar (PCA) plates were inoculated with $100 \mu \mathrm{l}$ of standardized inoculum $\left(1.5 \times 10^{6} \mathrm{CFU} / \mathrm{ml}\right)$ of each selected bacterium and spread with sterile swabs. Wells of $8 \mathrm{~mm}$ size diameter were made with sterile borer into agar plates containing the bacterial inoculum and the lower portion was sealed with a little molten agar medium. About $0.5 \mathrm{ml}$ volume of each of the extracts was poured into a well of inoculated plates. Streptomycin sulphate $(10 \mathrm{ug} / \mathrm{ml})$ was used as a positive control which was introduced into a well instead of extract. The solvents; deionized water, methanol or ethanol were used as a negative control which was introduced into a well instead of the extracts. The plates thus prepared were left at room temperature for ten minutes allowing the diffusion of the extract into the agar [18]. After incubation for 24 hrs at $37{ }^{\circ} \mathrm{C}$, the plates were observed. If antibacterial activity was present on the plates, it was indicated by an inhibition zone surrounding the well containing the vegetables extracts. The zone of inhibition was measured and expressed in $\mathrm{mm}$.

\subsubsection{Determination of Antifungal Activity}

The antifungal activity of the vegetables extracts was evaluated against food-associated fungi by using poisoned food technique. Potato dextrose agar (PDA), was weighed (39g) and was dispersed in a litre of deionised water sterilized at $121^{\circ} \mathrm{C}$ for $15 \mathrm{~min}$, allowed to cool $\left(45^{\circ} \mathrm{C}\right)$ before pouring $(20 \mathrm{ml})$ into separated dishes. The fungi; Fusarium solami, Trichoderma rubrum, and Aspergillus fumigates were inoculated on Potato dextrose agar (PDA) plates and incubated for $25^{\circ} \mathrm{C}$ for $72 \mathrm{~h}$, to obtain young, actively growing colonies of moulds. $0.2 \mathrm{ml}$ of each of the extract was mixed with $20 \mathrm{ml}$ of cooled $\left(45^{\circ} \mathrm{C}\right)$ molten PDA medium and allowed to solidify at room temperature for $30 \mathrm{~min}$. Thereafter $10 \mu \mathrm{l}$ of fungal spores in distilled water was added at the centre of the solidified PDA plates. PDA plates with $10 \mathrm{ug} / \mathrm{ml}$ of bonlate were used as positive control. PDA plates with the solvents; deionized water, methanol or ethanol were used as negative control [19] [20]. The inoculated plates were incubated at $25^{\circ} \mathrm{C}$ and colony mean diameter was measured and recorded after 3 days. Percentage mycelial growth inhibition (\% MGI) was calculated as given below:

$$
\% \mathrm{MGI}=\frac{\mathrm{DC}-\mathrm{DE} \times 100}{D C}
$$

MGI = Percentage mycelial growth inhibition

$\mathrm{DC}=$ Diameter of fungal colony in control

$\mathrm{DE}=$ Diameter of fungal colony in extract.

\subsection{Statistical Analysis}

Values are presented as the mean \pm SD of three replicates. ANOVA and Pearson correlation analyses were performed using the commercial software SPSS 16.0.

\section{Results and Discussion}

\subsection{Phytochemical Screening}

The aqueous and ethanol extracts of both B. alba and $S$. bifrae tested positive to saponin, flavonoids and steroid. Tannin was present in the aqueous and ethanol extracts of $B$. alba but not in $S$. bifrae while terpenoid was not detected in neither of the aqueous nor ethanol extracts of both vegetables. The methanol extracts of both vegetables were similar to aqueous and ethanol extracts except that they tested negative to steroid (Table 1) and only methanolic extract of $B$. alba tested positive to terpenoid. Oyewole and Kalejaiye, [2] observed the presence of tannin, terpenoid, steroid, saponins and anthraquinone in ethanolic extract of $B$. alba leaves while alkaloid and flavonoid were found to be absent. Ethanol extract of Senecio biafrae was also found to contain alkaloids, tannins, saponins, and steroids in very low concentrations in the study carried out by Gbadamosi and Okolosi, [21]. All the extracts tested negative to alkaloids, anthraquinone and phlobatannin. Cardiac glycosides are class of natural product, which are used to increase the 
cardiac contractile force in patients with congestive heart failure and cardiac arrhythmias [22]. Methanol extracts of both vegetables tested positive to Salkwoski test but negative to Lieberman test. All the extracts tested negative to Keller killiani test except the methanol extract of $B$. alba but positive to Legal test. The result of this screening is close to the findings of Ajiboye et al. [23] where an aqueous extract of Senecio biafrae leaves was found to test positive to steroids, glycosides, alkaloids, phenolic compounds, flavonoids, saponins, phlobatannin and tannins but negative to anthraquinones and terpenes.

The phytochemicals detected in the extracts of both vegetables in this study have been proved to serve various medicinal functions; saponins are natural antibiotics $[21,24,25]$, tannin promotes healing of wound and contain anti - diabetic properties [26,27] while steroidal compounds are of importance and interest in pharmacy due to their relationship with compounds such as sex hormones [28]. The presence of steroid may enhance the use of the plants as galactogogues by ensuring the synthesis of lactation hormones. The leaves of $B$. alba and $S$. biafrae may be useful as vegetables for expectant mothers or breast feeding mothers to ensure their hormonal balance [2,21,28].

\subsection{Antioxidant Properties (FRAP and TAP)}

The reducing power of the aqueous and alcohol extracts were assessed based on their abilities to reduce Fe (III) to Fe (II) and the results presented as ascorbic acid equivalent in mg/g. As revealed in Figure 1 and Figure 2, the reducing power of the aqueous extracts of $B$. alba and $S$. bifrae were higher than the alcohol extracts and this correlates to the total flavonoid contents (TFC) as rutin equivalent by reference to standard curve $(\mathrm{y}=8.250 \mathrm{x}$, $\left.\mathrm{r}^{2}=0.998\right)$. The TFC values in $\mathrm{mg} / \mathrm{g}$ for aqueous extracts of $B$. alba with the range $27.27 \pm 0.01$ to $139.39 \pm 0.01$ and S.biafrae, which range from $6.06 \pm 0.02$ to $42.42 \pm$ 0.03 are higher than those of alcoholic extracts which were in the range $0.76 \pm 0.02$ to $8.49 \pm 0.04$ and $0.61 \pm$ 0.02 to $4.18 \pm 0.03$ for B. alba and $0.82 \pm 0.01$ to $13.33 \pm$
0.01 and $1.21 \pm 0.01$ to $5.03 \pm 0.03$ for S.biafrae; methanol and ethanol extracts respectively. The higher TFC concentrations observed in the methanolic extracts of S.biafrae $(0.82 \pm 0.01$ to $13.33 \pm 0.01)$ than B.alba $(0.76 \pm$ 0.02 to $8.49 \pm 0.04)$ also correlates with higher reducing property observed in the same extract of S.biafrae than B.alba. Although, the ethanol extracts of $S$. bifrae gave significantly higher values of TFC $(p \leq 0.05)$ with the range $1.21 \pm 0.01$ to $5.03 \pm 0.03$ than $B$. alba; $0.61 \pm 0.02$ to $4.18 \pm 0.03$, the opposite was observed in their reducing power. Generally, the reducing power of all the extracts was also positively correlated to the total phenol contents (TPC) in $\mathrm{mg} / \mathrm{g}$ of $\mathrm{DW}$ as gallic acid equivalents by reference to standard curve $\left(\mathrm{y}=2.327, \mathrm{r}^{2}=0.9849\right)$. Higher total phenol contents were generally obtained in all the extracts of S.biafrae (48.52 \pm 0.01 to $64.71 \pm 0.01$; $42.97 \pm 0.01$ to $197.66 \pm 0.03$ and $9.02 \pm 0.01$ to $51.78 \pm$ 0.03 ) than B.alba (20.41 \pm 0.03 to $55.86 \pm 0.03 ; 42.97 \pm$ 0.02 to $83.79 \pm 0.16$ and $8.16 \pm 0.03$ to $39.10 \pm 0.02$ ) for aqueous, methanolic and ethanolic extracts respectively; the only exception is at $1-2 \mathrm{mg} / \mathrm{ml}$ of the methanolic extracts of the two vegetables where there was no significant difference $(p \leq 0.05)$ in the concentrations of TPC. In contrast however, the reducing properties of B.alba extracts were higher than those of S.biafrae except in the ethanol extracts. The observed variances could be due to the fact that different classes of phenolic compounds which exists in plants varies in potency and their solubility in different solvents; despite this, the correlation between the TFC and TPC (Table 2 and Table 3) with the reducing abilities of B.alba extracts was positively strong; TFC $(\mathrm{r}=0.944-0.967)$ and TPC ( $\mathrm{r}=0.937-0.970)$. Likewise, strong and positive correlations were observed between the reducing power of $S$. bifrae extracts and the TFC $(r=0.918-0.976)$ and TPC $(r=0.947-0.990)$ at between 0.01 and 0.05 significant levels. This supports the claims that flavonoids and other phenolic compounds of plant origin are powerful antioxidants [29]. The extracts exerted significant reducing abilities compared with the vitamin C standard as shown in Figure 1 and Figure 2.

Table 1. Phytochemical screening of aqueous and alcohol extracts

\begin{tabular}{|c|c|c|c|c|c|c|}
\hline \multirow[t]{2}{*}{ Extracts } & \multicolumn{2}{|c|}{ Aqueous } & \multicolumn{2}{|c|}{ Methanol } & \multicolumn{2}{|c|}{ Ethanol } \\
\hline & B. alba & S. biafrae & B. alba & S. biafrae & B. alba & S. biafrae \\
\hline Alkaloids & - & - & - & - & - & - \\
\hline Saponnin & + & + & + & + & + & + \\
\hline Tannin & + & - & + & + & + & - \\
\hline Flavonoid & + & + & + & + & + & + \\
\hline Steroid & + & + & - & - & + & + \\
\hline Terpenoid & - & - & + & - & - & - \\
\hline Anthraquinone & - & - & - & - & - & - \\
\hline Phlobatannin & - & - & - & - & - & - \\
\hline \multicolumn{7}{|c|}{ CARDIAC GLYCOSIDES } \\
\hline Legal test & + & + & + & + & + & + \\
\hline Salkwoski test & - & - & + & + & - & - \\
\hline Keller killiani & - & - & + & - & - & - \\
\hline Lieberman & + & + & - & - & + & + \\
\hline
\end{tabular}




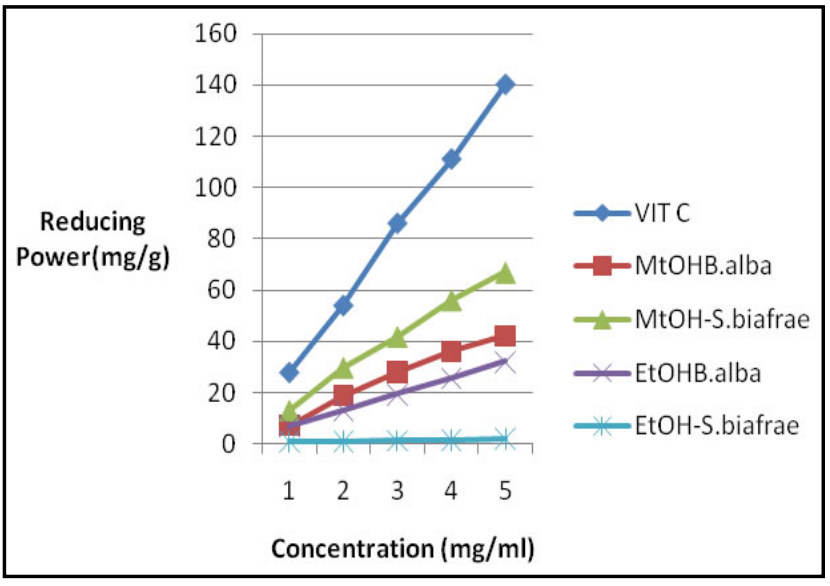

Figure 1. Ferric reducing antioxidant property (Alcohol extracts)

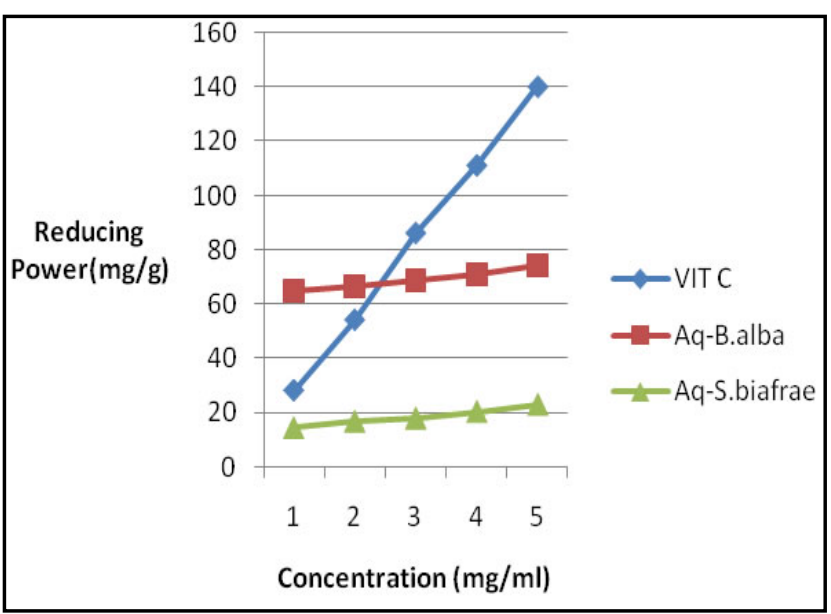

Figure 2. Ferric reducing antioxidant property (Aq extract)

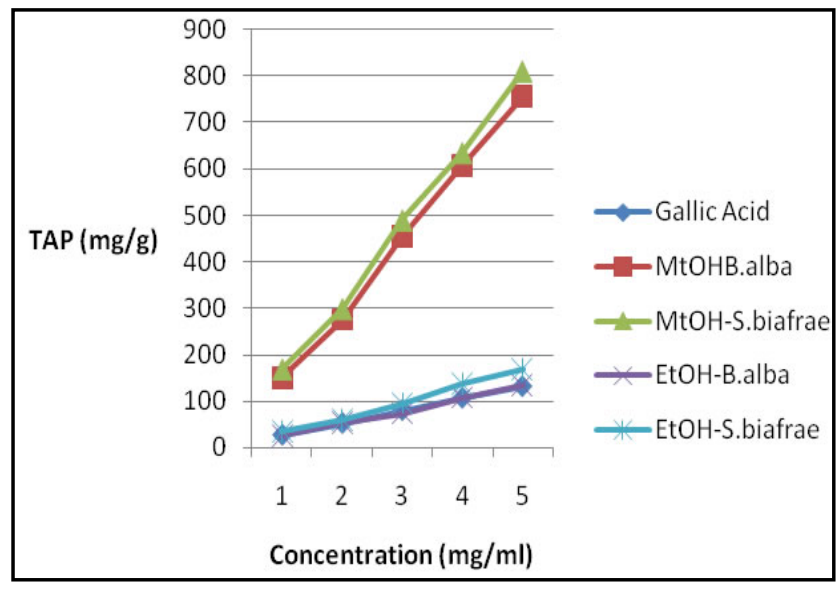

Figure 3. Total Antioxidant Property (Alcohol extracts)

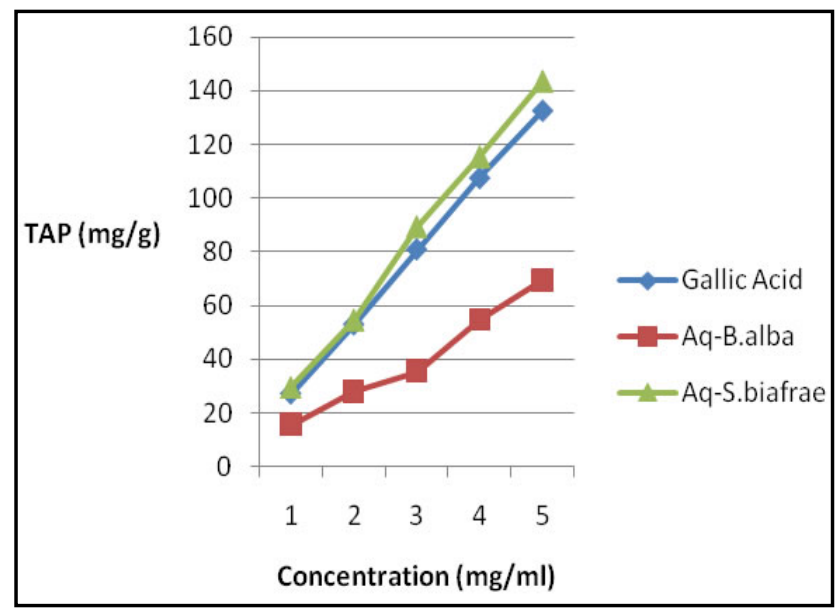

Figure 4. Total Antioxidant Property (Aqueous extract)

MtOHB.alba $=$ Methanol extract of B.alba

EtOHB.alba $=$ Ethanol extract of B.alba

MtOH S. biafrae = Methanol extract of S. biafrae

EtOH S. biafrae $=$ Ethanol extract of S. biafrae

Aq. B.alba $=$ Aqueous extract of B.alba

Aq. Biafrae $=$ Aqueous extract of biafrae.

Table 2. Pearson's correlation coefficient between total phenol content and antioxidant assays

\begin{tabular}{|c|c|c|c|c|}
\hline \multirow[t]{2}{*}{ ТPC } & & \multirow[t]{2}{*}{ Samples } & \multicolumn{2}{|c|}{ Pearson correlation } \\
\hline & & & FRAP & TAP \\
\hline \multirow[t]{4}{*}{ Aqueous } & r value & B. alba & $.970^{* * *}$ & $.945^{*}$ \\
\hline & $\mathrm{p}$ value & & .006 & .015 \\
\hline & r value & S. biafrae & $.947^{*}$ & $.966^{* *}$ \\
\hline & $\mathrm{p}$ value & & .015 & .008 \\
\hline \multirow[t]{4}{*}{ Methanol } & r value & B. alba & $.937^{*}$ & $.959^{* *}$ \\
\hline & $\mathrm{p}$ value & & .019 & .010 \\
\hline & r value & S. biafrae & $.958^{*}$ & $.985^{* *}$ \\
\hline & $\mathrm{p}$ value & & .010 & .002 \\
\hline \multirow[t]{4}{*}{ Ethanol } & r value & B. alba & $.948^{*}$ & $.980^{* *}$ \\
\hline & $\mathrm{p}$ value & & .014 & .003 \\
\hline & r value & S. biafrae & $.990^{* * *}$ & $.991^{* *}$ \\
\hline & $\mathrm{p}$ value & & .001 & .001 \\
\hline \multirow[t]{2}{*}{ Control } & & & $.991^{* *}$ & $.992^{* *}$ \\
\hline & & & .001 & .001 \\
\hline
\end{tabular}

${ }^{* *}$ Correlation is significant at 0.01 level (2-tailed), ${ }^{*}$ Correlation is significant at 0.05 level (2-tailed)

$\mathrm{TPC}=$ total phenol content. 
Table 3. Pearson's correlation coefficient between total flavonoid content and antioxidant assays

\begin{tabular}{|c|c|c|c|c|}
\hline \multirow[t]{2}{*}{ TFC } & & \multirow[t]{2}{*}{ Samles } & \multicolumn{2}{|c|}{ Pearson correlation } \\
\hline & & & FRAP & TAP \\
\hline \multirow[t]{4}{*}{ Aqueous } & r value & B. alba & $.946^{*}$ & $.989^{* *}$ \\
\hline & $\mathrm{p}$ value & & .015 & .001 \\
\hline & r value & S. biafrae & $.918^{*}$ & $.957^{*}$ \\
\hline & $\mathrm{p}$ value & & .028 & .011 \\
\hline \multirow[t]{4}{*}{ Methanol } & r value & B. alba & $.967^{* *}$ & $.991^{* *}$ \\
\hline & $\mathrm{p}$ value & & .007 & .001 \\
\hline & $r$ value & S. biafrae & $.961^{* *}$ & $.983^{* *}$ \\
\hline & $\mathrm{p}$ value & & .009 & .003 \\
\hline \multirow[t]{4}{*}{ Ethanol } & r value & B. alba & $.944^{*}$ & $.971^{* *}$ \\
\hline & $\mathrm{p}$ value & & .016 & .006 \\
\hline & r value & S. biafrae & $.976^{* *}$ & $.963^{* *}$ \\
\hline & $\mathrm{p}$ value & & .005 & .009 \\
\hline \multirow[t]{2}{*}{ Control } & & & $.968^{* *}$ & $.988^{* *}$ \\
\hline & & & .007 & .002 \\
\hline
\end{tabular}

${ }^{* *}$ Correlation is significant at 0.01 level (2-tailed), ${ }^{*}$ Correlation is significant at 0.05 level (2-tailed)

TFC = total flavonoid content.

Total Antioxidant Property assay assessed the reducing power of the extracts based on their abilities to reduce Mo (VI) to Mo (V) and the results presented in Figure 3 and Figure 4 as gallic acid equivalent in $\mathrm{mg} / \mathrm{g}$. $B$ alba and S. bifrae exhibited strong reducing capability on Mo (VI) in the aqueous and alcohol extracts compared with the gallic acid standard. Methanol extracts exerted better reducing power on Mo (VI) to Mo (V) transformation in this study than the aqueous and ethanol extracts in agreement with the trend observed for the TPC. Stronger ability to reduce Mo (VI) exhibited by the extracts of
S. biafrae also agrees with the trend observed for TPC. All the fractions showed substantial and concentration dependent increase in their reducing properties with positively strong correlations with corresponding TFC and TPC in the range TFC ( $\mathrm{r}=0.971-0.991)$; TPC $(\mathrm{r}=0.945-0.980)$ for B. alba and TFC $(\mathrm{r}=0.957-0.983)$; TPC ( $\mathrm{r}=0.966-0.991)$ for $S$. biafrae at $0.01-0.05$ significant levels (Table 2 and Table 3). 31.66 ( $\mu$ g vit E equivalent $/ 100 \mu \mathrm{g}$ ) was obtained for chloroform extract of Coccinia grandis in a study carried out by Umamaheswari and Chatterjee [30].

\section{Antibacterial activities of aqueous (Aq), methanol (MtOH) and ethanol (EtOH) extacts at $24 \mathrm{~h}$ incubation}

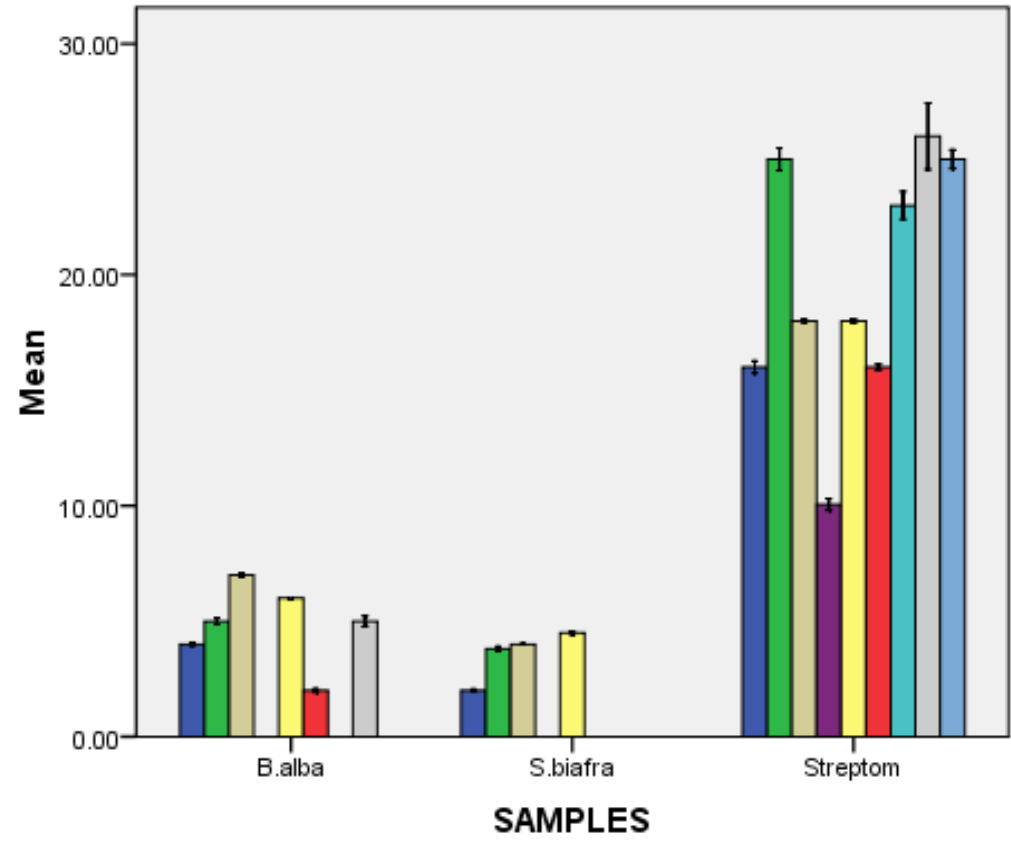

Error bars: +/. 2 SD
Aq.S.aureus $\square \mathrm{MeOH} . \mathrm{S}$.aureus $\square \mathrm{EtOH} . \mathrm{S}$.aureus

Aq.P.aeruginosa $\square$ MeOH.P.aeruginosa EtOH.P.aeruginosa $\square$ Aq.S.typhi $\square \mathrm{MeOH}$.S.typhi $\square$ EtOH.S.typhi

Figure 5. Antibacterial property 


\section{Antifungal activities of aqueous ( $\mathrm{Aq})$, methanol (MtOH) and ethanol (EtOH) extracts at $24 \mathrm{hr}$ incubation}
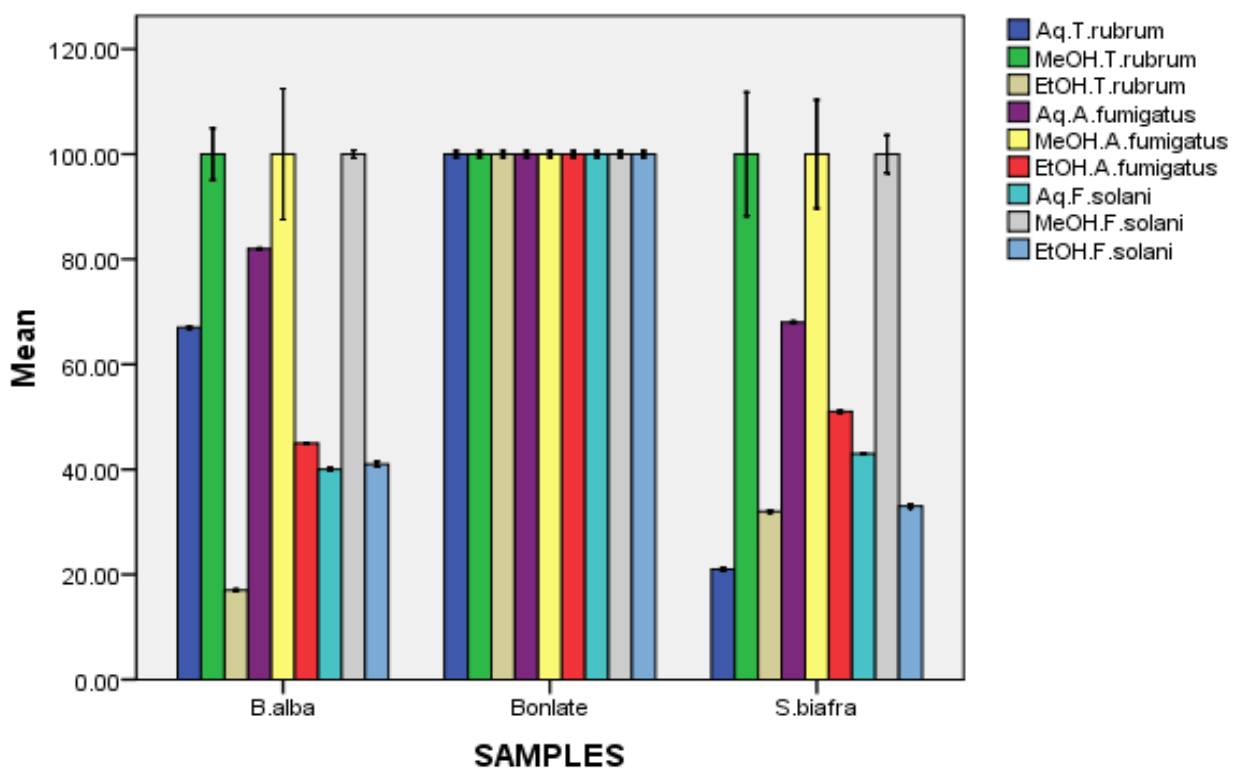

Error bars: +/. $2 \mathrm{SE}$

Figure 6. Antifungal property

\subsection{Antimicrobial Activities of Vegetables Extracts}

The antibacterial activities of leaves extracts of S. biafrae and B. alba are shown in Figure 5. The results showed that the aqueous extracts of $S$. biafrae and B. alba had no inhibitory activity against P.aeruginosa and $S$. typhi but $S$. aureus was inhibited by the aqueous extracts of both vegetables. This observation may be attributed to the fact that aqueous extracts of $S$. biafrae and $B$. alba are effective against gram positive bacteria than gram negative bacteria. Ethanolic extract of B.alba had the highest activity against $S$. biafrae when compared with the other extacts of $B$. alba and $S$. biafrae. The results also showed that both $S$. biafrae and P.aeruginosa were susceptible to ethanolic extract of B.alba while S. typhi was resistant. This is similar to the findings of Oyewole and Kalejaiye [2], and Sushila et al., [31]. Oyewole and Kalejaiye [2] reported that $S$. aureus, P.aeruginosa and E.coli were susceptible to the ethanolic extract of the leaves of B.alba. Among the extracts of S. biafrae, methanolic extract had the highest inhibitory effect on P.aeruginosa.

The results of the antifungal properties of the extracts of S. biafrae and B. alba; presented in Figure 6 showed that the methanolic extracts of both vegetables had $100 \%$ mycelia growth inhibition against $T$. rubrum, A. fumigates and $F$. solani. The aqueous extract of $S$. biafrae had the lowest mycelia growth inhibition against $T$. rubrum when compared with other extracts of S. biafrae in this study; and T. rubrum was least susceptible to the extracts of both vegetables. It can be deduced from the results of this study that the vegetables extracts displayed higher susceptibility to fungi than bacteria, but both $B$. alba and S. biafrae demonstrated similar antifungi properties.

B.alba extracts contained stronger antibacterial compounds than S. biafrae, both S. biafrae and B. alba extracts however showed appreciable antimicrobial activities. Their extracts may be developed as antifungal agents for treatment of infections as well as food preservatives.

\section{Conclusion}

Aqueous and alcohol extracts of B.alba and S. biafrae generally demonstrated concentration dependent effectiveness in their reducing power and antimicrobial properties; and there was positively strong correlation between the reducing properties and the total phenol and total flavonoid contents of the extracts. Their reducing ability is an indication of the antioxidant potential of the flavonoids and other phenolic compounds present in these vegetables. Large scale cultivation and utilization of these vegetables could be of great health benefit and economic potential.

Acknowledgement: I am grateful to Mr, Igbeh Festus and Mr Hassan both in Federal University of Technology, Akure, ondo State, Nigeria for their assistance throughout the period of this study and every one, who in one way or the other has contributed to the successful completion of this work.

\section{Statement of Competing Interests}

The author has no competing interests.

\section{List of Abbreviations}

TPC $=$ Total phenol content

TFC $=$ Total flavonoid content

MtOHB.alba = Methanol extract of B.alba

EtOHB.alba = Ethanol extract of B.alba 
MtOH S. biafrae = Methanol extract of S. biafrae

EtOH S. biafrae = Ethanol extract of $S$. biafrae

Aq. B.alba $=$ Aqueous extract of B.alba

Aq. biafrae $=$ Aqueous extract of biafrae

Aq. $S$. aureus = Antibacterial activity of Aqueous extract against $S$. aureus

MtOH. S. aureus = Antibacterial activity of methanol extract against $S$. aureus

EtOH S. aureus = Antibacterial activity of ethanol extract against $S$. aureus

Aq. P.aeruginosa $=$ Antibacterial activity of Aqueous extract against $P$.aeruginosa

MtOH P.aeruginosa $=$ Antibacterial activity of methanol extract against P.aeruginosa

EtOH P.aeruginosa $=$ Antibacterial activity of ethanol extract against P.aeruginosa

Aq. S.typhi = Antifungal activity of Aqueous extract against S.typhi

MtOH S.typhi = Antifungal activity of methanol extract against S.typhi

S.typhi = Antifungal activity of ethanol extract against S.typhi

Aq. T.rubrum $=$ Antibacterial activity of Aqueous extract against T.rubrum

MtOH.T.rubrum = Antibacterial activity of methanol extract against T.rubrum

EtOH T.rubrum = Antibacterial activity of ethanol extract against T.rubrum

Aq. A.fumigatus = Antibacterial activity of Aqueous extract against $A$.fumigatus

MtOH A.fumigatus = Antibacterial activity of methanol extract against $A$.fumigatus

EtOH A.fumigatus = Antibacterial activity of ethanol extract against A.fumigatus

Aq. F.solami $=$ Antifungal activity of Aqueous extract against F.solani

MtOH F.solami = Antifungal activity of methanol extract against F.solani

EtOH F.solami = Antifungal activity of ethanol extract against F.solani

\section{References}

[1] Abalaka, M. E. and Oyewole O.A., "Antibacterial Activities of Asmina triloba against Some Bacterial Pathogens,” J. Micro. Res. 1(1), 5-7. January 2011.

[2] Oyewole, O. A. and Kalejaiye, O. A., "The antimicrobial activities of ethanolic extracts of Basella alba on selected microorganisms" Scientific Journal of Microbiology, 1(5), 113-118. October 2012

[3] Kumar, S., Prasad, A. K.., Iyer, S. V. and Vaidya, S. K. "Systematic pharmacognostical, phytochemical and pharmacological review on an ethno medicinal plant, Basella alba L," Journal of Pharmacognosy and Phytotherapy, 5(4), 53-58. February 1983.

[4] Aja, P. M., Okaka, A. N. C., Onu, P. N., Ibiam, U.and Urako, A. J., "Phytochemical Composition of Talinum triangulare (Water Leaf) Leaves,” Pakistan Journal of Nutrition, 9 (6), 527-530. June 2010.

[5] Zheng, W and Wang, S.Y., "Antioxidant activity and phenolic compounds in selected herbs,” J Agric Food Chem 49(11), 51655170. September 2001.

[6] Ajiboye, B. O., Ibukun, E. O., Edobor, G., Ojo, A. O. and Onikanni, S. A., "Qualitative and quantitative analysis of phytochemicals in Senecio Biafrae Leaf” International Journal Of Inventions In Pharmaceutical Sciences, 1(5), 428-432. August 2013.
[7] Okoro, O., Umar, A., Atawodi, S. E. and Anigo, K. M., "Comparative antihyperglycemic effect of petroleum ether, acetone, ethanol and aqueous extracts of Cleome rutidosperma DC and Senecio biafrae (Oliv. and Hiern) in Streptozotocin-induced Diabetic Mice,” British Journal of Pharmacology and Toxicology 5(3), 115-124. June 2014.

[8] Oloyede, F. M., Oloyede, F. A. and Obuotor, E. M., "Comparative studies of chemical compositions of two species of Basella” .App. Sci. Report. 3 (2), 121-124. 2013.

[9] Dairo, F. A. S and Adanlawo, I. G., "Nutritional quality of Crassocephalum crepidioides and Senecio biafrae," Pakistan J. Nutrit., 6(1). 35-39. 2007.

[10] Iweala, E. J. and Okeke, C. U., "Comparative study of the hypoglycemic and biochemical effects of Catharanthusroseus (Linn) g. apocynaceae (Madagascar periwinkle) and chlorpropamide (diabenese) on alloxan-induced diabetic rats" BIOKEMISTRI, 17(2), 149-156. December 2005.

[11] Harborne, J. B., Phytochemical methods, a guide to modern techniques of plant analysis, Chapman and Hall Ltd., New York, 1984, 49-188.

[12] Trease, G. E. and Evans, W. C. (2002). Phytochemicals. In: Pharmacognosy, Saunders Publishers, London, 2002.

[13] Sofowora, A., Medicinal plants and traditional medicines in Africa. Chichester John Wiley and Sons, New York. 1993, 97-145.

[14] Pulido, R., Bravo, L. and Saura-Calixto F., "Antioxidant activity of dietary polyphenols as determined by a modified ferric reducing antioxidant power assay," Journal of Agricultural and Food Chemistry, 48 (8), 3396-3402. August 2000.

[15] Prieto, P., Pineda, M. and Aguilar, M., "Spectropho tometric quantitation of antioxidant capacity through the formation of phosphomolybdenum complex: pecific application to the determination of vitamin E.," Analytical Biochemistry, 269, 337-341. May 1999.

[16] Ahmad, I. and Beg A. J., "Antimicrobial and Phytochemical Studies on 45 Indian Medicinal Plants Against Multidrug Resistant Human Pathogens,” Journal of Ethnopharmacology, 74 (2), 113-123. February 2011.

[17] Srinivasan, D., Nathan, S., Suresh, T. and Perumalsamy, P. L., "Antimicrobial activity of certain Indian medicinal plants used in folkloric medicine,” Journal Ethnopharmacology, 74, 217-220. March 2001.

[18] Rios, J. L., Recio, M. C., Villar, A. "Screening methods for natural products with antimicrobial activity: a review of the literature," Journal of Ethnopharmacology, 23, 127-149. July- August 1988.

[19] McCutcheon, A. R., Ellis, S. M., Hancock, R. E. W. and Tower, G. H. N., "Antifungal screening of medicinal plants of British Columbian native people,” Journal of Ethanopharmacology, 44: 157-169. December 1994.

[20] Georgii, A. and Korting, H. C., “Antifungal susceptibility testing with dermatophytes,” Mycoses, 34, 193-199. May 1991.

[21] Gbadamosi, I. T. and Okolosi, O. "Botanical galactogogues: nutritional values and therapeutic potentials” Journal of Applied Biosciences, 61, 4460-4469. January 2013.

[22] Hauptman, P. J, and Garg, R, and Kelly, R. A., "Cardiac glycosides in the next millennium," Progress in Cardiovasc. Disease. 41(4), 247-254. February 1999.

[23] Ajiboye, B. O., Ibukun, E. O., Edobor, G., Ojo, A. O. and Onikanni, S.A., "Qualitative and quantitative analysis of phytochemicals in Senecio biafrae leaf,” International Journal of Inventions in Pharmaceutical Sciences, 1(5), 428-432. 2013.

[24] Akindahunsi,, A. A. and Salawu, S. O., "Phytochemical screeninig nutrient and anti-nutrient compositions of selected tropical green leafy vegetables," African Journal of Biochemistry, 4: 97-105. 2005.

[25] Prohp, T. P. and Onoagbe, I. O., "Determination of phytochemical composition of the stem bark of triplochitonscleroxylonk. schum. (sterculiaceae)," International Journal of Applied Biology and Pharmaceutical Technology, 3 (2), 68-76. April - June 2012.

[26] Okwu, D. E. and Josiah C., "Evaluation of the chemical composition of two Nigerian medicinal plants," African Journal of Biotechnology, 5 (4), 357-361. February 2006.

[27] Iwu, M. M., "Hypoglycemic properties of Bridelia furruginear leaves,” Fitoterapia, 54, 243 -248. March 1983.

[28] Okwu, D. E., "Evaluation of the chemical composition of indigenous spices and flavouring agents," Global Journal of Pure and Applied Science 7(3): 455- 459. 2001. 
[29] Rice-Evans, C. A., Miller, N. J., Paganga, G., "Antioxidant properties of phenolic compounds," Trends in Plant Science, 2(4), 152-159. 1997

[30] Umamaheswari,, M. and Chatterjee, T. K., "In Vitro Antioxidant activities of the fractions of Coccinia grandis L. leaf extract,"
African Journal of Traditional, Complementary and Alternative Medicine, 5 (1), 61-73. October 2008.

[31] Sushila, R., Deepti, A., Permender, R., Madhavi, T., Dharmender, R., "Cytotoxic and antibacterial activity of Basella alba whole plant,” Pharmacol., 3(1), 651-658. 2010. 